\title{
Correction to: Application of the Gauss-Bonnet theorem to lensing in the NUT metric
}

\author{
Mourad Halla $^{1}$ (D) . Volker Perlick ${ }^{1}$
}

Published online: 16 July 2021

(c) The Author(s) 2021

\section{Correction to: General Relativity and Gravitation (2020) 52:112 https://doi.org/10.1007/s10714-020-02766-z}

The article Application of the Gauss-Bonnet theorem to lensing in the NUT metric, written by Mourad Halla and Volker Perlick, was originally published Online First without Open Access. After publication in volume 52, issue 11, page 112 the author decided to opt for Open Choice and to make the article an Open Access publication. Therefore, the copyright of the article has been changed to The Author(s) 2020 and the article is forthwith distributed under the terms of the Creative Commons Attribution Attribution 4. 0 International License, which permits use, sharing, adaptation, distribution and reproduction in any medium or format, as long as you give appropriate credit to the original author(s) and the source, provide a link to the Creative Commons licence, and indicate if changes were made. The images or other third party material in this article are included in the article's Creative Commons licence, unless indicated otherwise in a credit line to the material. If material is not included in the article's Creative Commons licence and your intended use is not permitted by statutory regulation or exceeds the permitted use, you will need to obtain permission directly from the copyright holder. To view a copy of this licence, visit http://creat ivecommons.org/licenses/by/4.0.

Open Access This article is licensed under a Creative Commons Attribution 4.0 International License, which permits use, sharing, adaptation, distribution and reproduction in any medium or format, as long as you give appropriate credit to the original author(s) and the source, provide a link to the Creative Commons licence, and indicate if changes were made. The images or other third party material in this article

The original article can be found online at https://doi.org/10.1007/s10714-020-02766-z.

Mourad Halla

mourad.halla@zarm.uni-bremen.de

Volker Perlick

perlick@zarm.uni-bremen.de

1 ZARM, University of Bremen, 28359 Bremen, Germany 
are included in the article's Creative Commons licence, unless indicated otherwise in a credit line to the material. If material is not included in the article's Creative Commons licence and your intended use is not permitted by statutory regulation or exceeds the permitted use, you will need to obtain permission directly from the copyright holder. To view a copy of this licence, visit http://creativecommons.org/licen ses/by/4.0/.

Publisher's Note Springer Nature remains neutral with regard to jurisdictional claims in published maps and institutional affiliations. 